\title{
Ophiostomatoid fungi associated with mangroves in South Africa, including Ophiostoma palustre sp. nov.
}

\author{
J. Alexander Osorio ${ }^{1}$, Z. Wilhelm De Beer ${ }^{1}$, Michael J. Wingfield ${ }^{1}$, Jolanda Roux ${ }^{2,3}$ \\ ${ }^{1}$ Department of Microbiology and Plant Pathology, DST/NRF Centre of Excellence in Tree Health Biotechnology \\ (CTHB), Forestry and Agricultural Biotechnology Institute (FABI), University of Pretoria, Private Bag X20, \\ Pretoria, Gauteng, South Africa. \\ ${ }^{2}$ Department of Plant and Soil Sciences, DST/NRF Centre of Excellence in Tree Health Biotechnology (CTHB), \\ Forestry and Agricultural Biotechnology Institute (FABI), University of Pretoria, Private Bag X20, Pretoria, \\ Gauteng, South Africa. \\ ${ }^{3}$ Corresponding author; e-mail: jolanda.roux@ fabi.up.ac.za
}

\begin{abstract}
Mangrove trees are continuously under stress due to environmental and/or anthropogenic pressures, which expose them to attack by pathogens, compromising their survival.

Ophiostomatoid fungi cause sap stain and diseases of a wide spectrum of tree species globally. These fungi infect trees through natural, insect, animal and/or human made wounds. During routine surveys of mangrove trees in South Africa, wounds on branches and stems of Avicennia marina were regularly monitored for the presence of ophiostomatoid fungi at ten study sites in the country. The stems of four mangrove species, Avicennia marina, Bruguiera gymnorrhiza, Rhizophora mucronata and Barringtonia racemosa were also wounded and evaluated for the appearance of these fungi. Ophiostomatoid fungi were obtained from the mangrove associate $B$. racemosa, but not from any of the true mangroves. Analyses of DNA sequence data for the Internal Transcribed Spacer (ITS), $\beta$-tubulin (BT), Calmodulin (CAL) and Translation Elongation Factor (TEF) gene regions revealed that the fungi isolated from the wounds on B. racemosa belong to three species in the Ophiostomataceae, including a new taxon described here as Ophiostoma palustre sp. nov. Results suggest that the mangrove associate $B$. racemosa is more prone to colonization by ophiostomatoid fungi than the true mangroves.
\end{abstract}

Key words: Barringtonia, Ophiostomatales, Sporothrix, wound infection. 


\section{Introduction}

Mangrove trees and shrubs occur along intertidal zones of approximately 123 tropical and subtropical countries globally (Spalding et al. 2010). They are well known for their morphological and physiological adaptations that allow them to survive in extreme environments characterized by high salt concentration levels, anoxic and unstable soils. Two different groups of mangroves are recognized based on their efficiency to permanently thrive in these environments. They include the true mangroves, considered halophytes that form pure stands, and the mangrove associates which are glycophytes with a certain degree of salt tolerance and that can extend into terrestrial communities, or grow at the margins of mangrove areas (Tomlinson 1986; Wang et al. 2010). The mangroves provide multiple essential services including coastal protection, habitats for terrestrial and aquatic fauna, food and fuel for local communities (Tomlinson 1986; Nagelkerken et al. 2008). However, despite their importance, human activities are placing significant pressure on these ecosystems, with many being on the brink of extinction (Valiela et al. 2001; Alongi 2002; Duke et al. 2007).

Six species of true mangroves and two mangrove associates occur along the eastern coast of South Africa (Steinke 1999). While anthropogenic pressures are considered a significant threat to the survival of these trees in the country (Adams et al. 2004; Rajkaran et al. 2009), the recent discovery of a fungal disease of the mangrove associate, Barringtonia racemosa (Osorio et al. 2015), and reports of trees dying of unknown causes, prompted disease surveys of these trees in South Africa. During these disease surveys, wounds on these trees, due to mostly human activities and wood-boring insects, were often observed. These lesions, when fresh, would be ideal for infection by ophiostomatoid fungi.

The term ophiostomatoid fungi refers to an artificial group of fungi characterized by the production of spores encapsulated in sticky masses at the apices of well-developed, erect and elevated ascomatal necks or conidiophores, facilitating their dispersion by a variety of arthropods (Wingfield et al. 1993; Kirisits 2004; Harrington 2005). This distinctive strategy for spore dissemination is characteristic of sexual and some asexual stages of a wide variety of morphologically similar species in the Ophiostomatales and Microascales (Ascomycota) (Malloch and Blackwell 1993; De Beer et al. 2013). These orders include many economically important tree pathogens and wood-staining fungi (De Beer et al. 2013). The detrimental effects of ophiostomatoid fungi and their vectors on their host trees are well documented and some devastating tree pathogens reside in this group (Wingfield et al. 1993; Jacobs and Wingfield 2001; Sinclair and Howard 2005; Roux and Wingfield 2009; Seifert et al. 2013). 
The Ophiostomatoid fungi can be separated into two distinct groups; those residing in the Ophiostomatales and those in the Microascales. The former group includes well known pathogens such as Ophiostoma ulmi and O. novo-ulmi causing Dutch elm disease in Europe and North America (Brasier 2000). Similarly, Raffaelea lauricola and Raffaelea quercivora are respectively associated with the mass mortality of Lauraceae in the United States (USA) and Quercus species in Japan (Kubono and Ito 2002; Fraedrich et al. 2008) and three varieties of Leptographium wageneri are associated with black stain root disease of conifers (Harrington and Cobb 1988; Jacobs and Wingfield 2001). In the Microascales, species in various genera of the Ceratocystidaceae are serious pathogens (Roux and Wingfield 2009; De Beer et al. 2013). For example, Ceratocystis albifundus is an important pathogen of Acacia mearnsii in South Africa (Roux et al. 1999), C. manginecans causes a serious disease of mango and Acacia mangium trees (Van Wyk et al. 2007; Tarigan et al. 2011) and Ceratocystis fagacearum causes oak wilt in North America (Henry et al. 1944, Juzwik et al. 1998). Other members of the ophiostomatoid fungi are, however, considered to be saprophytes or agents of sap stain (Seifert et al. 1993; Thwaites et al. 2005; Harrington et al. 2010).

Wounds are essential as entry points for ophiostomatoid fungi to infect trees (Gibbs 1993; Kile 1993). Experiments where trees in natural forests or plantations were wounded (e.g. Geldenhuis et al. 2004; Roux et al. 2004, 2007; Tarigan et al. 2010) have confirmed the ability of these fungi to infect trees through these wounds. In general, natural infections might be the result of wind or rain splash dispersal of spores, or by transmission of inoculum by arthropod vectors such as bark beetles, nitidulid beetles and mites (Malloch and Blackwell 1993; Six 2003; Klepzig and Six 2004; Hayslett et al. 2008; Juzwik et al. 2008). The avoidance of wounds is, therefore, a key management recommendation to reduce the impact of wood stain and disease caused by these fungi in fruit orchards, plantations and ornamental trees.

Other than one unnamed Sporothrix sp. from China (Wen et al. 2009), we are unaware of other studies of ophiostomatoid fungi on mangroves. The aim of this study was, therefore, to investigate the possible occurrence of ophiostomatoid fungi on mangrove trees in South Africa. To achieve this we made wounds on true and associate mangrove trees in six mangrove forests in South Africa, and isolated and identified ophiostomatoid fungi collected from them. 


\section{Materials and methods}

\section{Tree species sampled}

To standardize sample size and wound age over sites, fresh wounds of a specific size and nature were made on the stems of selected mangroves species. Avicennia marina (100 trees at five sites), Bruguiera gymnorrhiza (100 trees at five sites), Rhizophora mucronata (60 trees at three sites) and Barringtonia racemosa (80 trees at one site) were chosen for the experiment because they are the most commonly occurring mangrove tree species in South Africa. The stem-wounding trials were carried out at the KwaZulu-Natal Province at Beachwood Nature Reserve (294' $\left.19.01^{\prime \prime S}, 31^{\circ} 02^{\prime 2} 28.90^{\prime \prime E}\right)$ a site dominated by dense stands of A. marina and B. gymnorrhiza, while few individuals of $R$. mucronata are present; Isipingo (29 59'32.10"S, 30 56'59.72"E) characterized by scattered A. marina, B. gymnorrhiza and $R$. mисronata; Mapelane Nature Reserve (28²9'19.06"S, 32²3'49.46"E) where the swamp forest is dominated by dense stands of B. racemosa; Mlalazi Nature Reserve at Mtunzini (28 $\left.57^{\prime} 15.39^{\prime \prime S}, 31^{\circ} 46^{\prime} 23.03^{\prime \prime E}\right)$, characterized by A. marina and B. gymnorrhiza stands and St. Lucia (28 $\left.22^{\prime} 44.87^{\prime \prime S}, 32^{\circ} 25^{\prime} 22.67^{\prime \prime E}\right)$, with A. marina and B. gymnorrhiza. In the Eastern Cape Province, wounds were made at Mgazana estuary (3141'44.97"S, 29²4'32.24"E) where large-scale harvesting of mangroves takes place. The area supports $A$. marina, $B$. gymnorrhiza and R. mucronata (Fig. 1). All trials were conducted with the permission of the appropriate conservation authorities (Ezemvelo KZN Wildlife; Eastern Cape Parks \& Tourism Agency)

In the first set of experiments, 20 apparently healthy trees with a diameter at breast height (DBH) greater than $10 \mathrm{~cm}$ per tree species (i.e., A. marina, B. gymnorrhiza and $R$. mucronata) were randomly selected at each area and one wound was made per tree, at approximately $1.5 \mathrm{~m}$ above soil level. The first wounding experiment was carried out in October and the second in November 2013 at the sites mentioned above. Based on results of these experiments, additional wounding trials were established at Mapelane and St. Lucia, on A. marina, B. gymnorrhiza and the mangrove associate B. racemosa, where an additional 20 trees of each species were wounded in February, April and June of 2014. An axe was used to remove $\sim 10 \times 10 \mathrm{~cm}$ square pieces of the bark to expose the cambium of trees. The edges of the bark were lifted to make a space between the bark and cambium to produce bark flaps under which insects and wound-infecting fungi could become established. Additionally, several cuts $\sim 10 \mathrm{~mm}$ deep were made, using a chisel or machete and a hammer, into the xylem in the areas where the bark had been removed. Portions of the bark were replaced, 
where possible, and loosely secured with masking tape around the stems to avoid desiccation of the wounds. After six weeks, each wounded tree was examined for the presence of ophiostomatoid fungi. The plant samples were then placed in separate plastic bags and transported to the laboratory facilities of the Forestry and Agricultural Biotechnology Institute (FABI), University of Pretoria for fungal isolation.

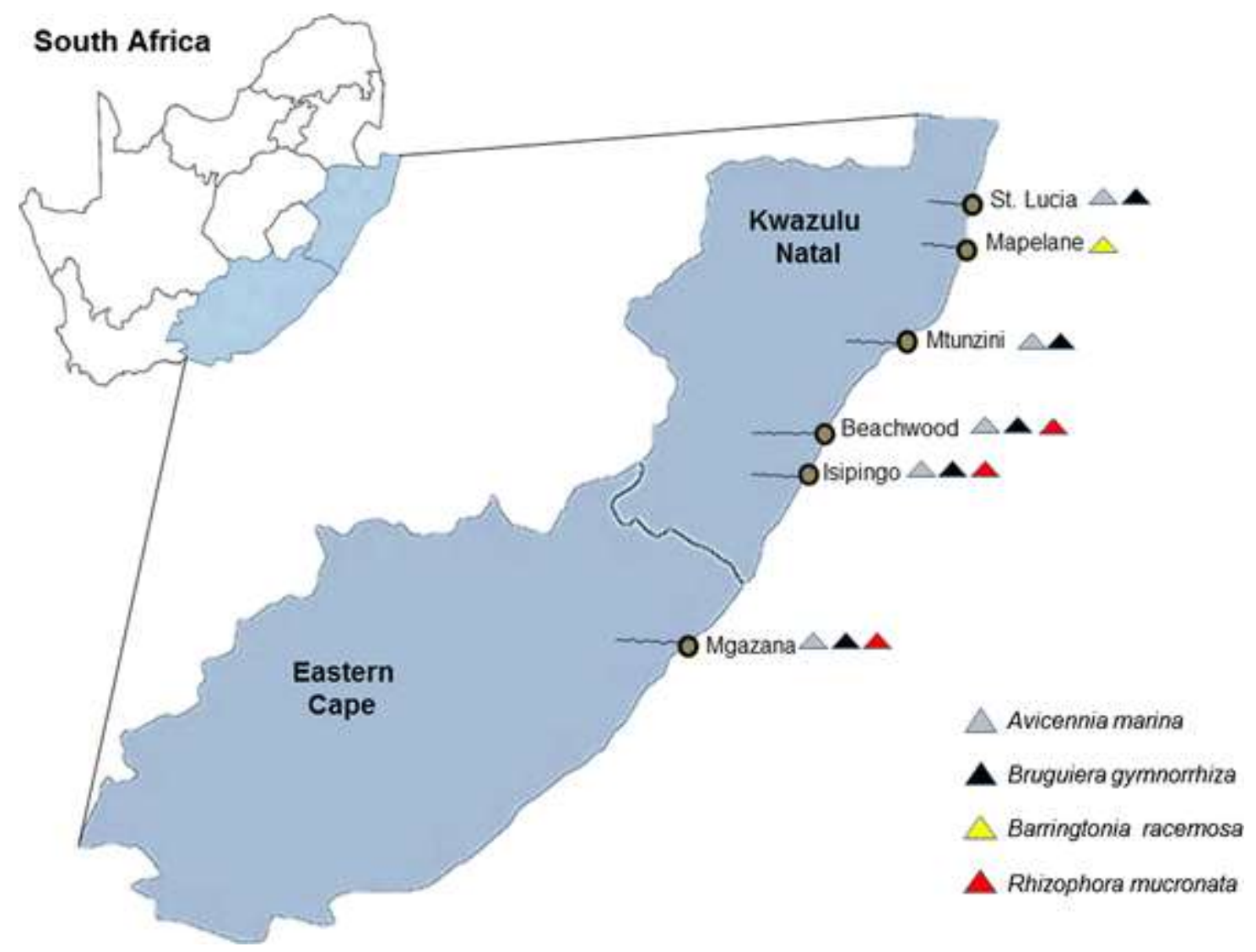

Fig. 1 Mangrove species artificially wounded (triangle colors) and the sites (circles) where the experiments were conducted.

\section{Fungal isolations}

Portions of bark and cambium were screened for the presence of fungal structures typical of those of the ophiostomatoid fungi using a Nikon SMZ 745 dissection microscope. Isolations were made directly from spore masses developing at the apices of ascomata or by plating out $\sim 5 \mathrm{~mm}^{2}$ sections of surface sterilized $(70 \% \mathrm{EtOH})$ plant material, showing symptoms of sap stain, onto $2 \%$ Malt extract agar (MEA; $15 \mathrm{~g}$ agar and $20 \mathrm{~g}$ malt extract $\mathrm{l}^{-1}$ ) containing $0.4 \mathrm{~g}$ streptomycin sulfate $\mathrm{l}^{-1}$ (Sigma-Aldrich, USA) and/or onto $2 \%$ MEA medium containing 0.5 $\mathrm{g}$ of cycloheximide $\mathrm{l}^{-1}$ (Sigma-Aldrich, USA) for the isolation of ophiostomatoid fungi 
(Harrington 1981). Plates were incubated at $25^{\circ} \mathrm{C}$. Pure cultures resembling ophiostomatoid fungi were deposited in the culture collection (CMW) of the Forestry and Agricultural Biotechnology Institute (FABI), University of Pretoria, and duplicate cultures of novel species were deposited in the culture collection of the CBS-KNAW (Centraalbureau, Schimmelcultures) Fungal Biodiversity Centre, Utrecht, The Netherlands. Type specimens were deposited in the fungarium of the National Collection of Fungi (PREM, Pretoria, South Africa).

\section{Fungal identification}

\section{DNA extraction, PCR and sequencing}

Genomic DNA was extracted from fungal cultures by placing mycelium of one-week -old cultures into $2 \mathrm{~mL}$ sterile Eppendorf tubes for freeze drying. The mycelium was pulverized using a Mixer Mill type MM 301 Retsch $^{\mathrm{R}}$ tissue lyser (Retsch, Germany) for 3 min at a frequency of 30 cycles per second. DNA was extracted following the methodology described by Raeder and Broda (1985). The resulting DNA was subsequently suspended in $50 \mu \mathrm{L}$ $\mathrm{ddH}_{2} \mathrm{O}, 5 \mu \mathrm{L}$ RNAse was added and incubated at $37{ }^{\circ} \mathrm{C}$ for $60 \mathrm{~min}$. A NanoDrop ND-1000 spectrophotometer (NanoDrop Technologies, USA) was used to measure the quality and quantity of the extracted DNA.

The ITS region was amplified with the primer pair ITS1/ITS4 (White et al. 1990). In cases where the amplification was not successful, primer ITS1 was replaced by ITS1F (Gardes and Bruns 1993). PCR amplification of the ITS region consisted of $25 \mu \mathrm{L}$ reaction mixture containing $2 \mu \mathrm{L}$ of DNA (20 ng), $2.5 \mu \mathrm{L}$ 10x PCR reaction buffer (containing $\left.\mathrm{MgCl}_{2}\right), 2.5 \mu \mathrm{L}$ dNTP $(5 \mathrm{mM}), 0.5 \mu \mathrm{L}$ of each primer $(10 \mathrm{mM}), 0.2 \mu \mathrm{L}$ Faststart Taq DNA Polymerase (Roche Applied Science, Mannheim, Germany), $5 \mu \mathrm{L}$ GC rich solution (Roche Applied Science, Mannheim, Germany), and $0.5 \mu \mathrm{L}$ extra $\mathrm{MgCl}_{2}(25 \mathrm{mM})$. To adjust the reaction mixture to $25 \mu \mathrm{L}, \mathrm{ddH}_{2} \mathrm{O}$ was added.

Three additional loci were amplified to elucidate the species placement where the ITS region was not sufficient. Part of the Beta-tubulin (BT) gene was amplified using the primers BT2a and BT2b (Glass and Donaldson 1995), the Calmodulin (CAL) gene region was amplified using CL2F and CL2R (Duong et al. 2012) and a portion of the Translation Elongation Factor 1- $\alpha$ (TEF) was amplified using EF1F and EF2R (Jacobs et al. 2004). For DNA amplification of these three gene regions, the same volumes were used as for ITS, 
except for the GC solution, which was not used. All reactions were performed using the following thermal cycling conditions: initial denaturation at $94{ }^{\circ} \mathrm{C}$ for $4 \mathrm{~min}$ followed by ten cycles consisting of $94{ }^{\circ} \mathrm{C}$ for $20 \mathrm{~s}, 53{ }^{\circ} \mathrm{C}$ (CAL) and $55{ }^{\circ} \mathrm{C}$ (ITS, BT, TEF) for $48 \mathrm{~s}, 72{ }^{\circ} \mathrm{C}$ for $45 \mathrm{~s}$, followed by a further 25 cycles of $94^{\circ} \mathrm{C}$ for $20 \mathrm{~s}, 53{ }^{\circ} \mathrm{C}$ (CAL) and $55^{\circ} \mathrm{C}$ (ITS, BT, TEF) for $40 \mathrm{~s}$ with a time increase of $5 \mathrm{~s}$ each cycle, and $72{ }^{\circ} \mathrm{C}$ for $45 \mathrm{~s}$. This was concluded by a final elongation step at $72{ }^{\circ} \mathrm{C}$ for $10 \mathrm{~min}$. An aliquot of $5 \mu \mathrm{L}$ of each PCR product was stained with GelRed ${ }^{\mathrm{TM}}$ nucleic acid gel stain (Biotium, USA), separated on a $1 \%$ agarose gel for 20 min at 90 Volts and viewed with the Gel Doc EZ Imager (Bio-Rad Laboratories Inc.).

PCR products were cleaned using the Exonuclease I - Shrimp Alkaline Phosphatase (Exo-SAP) or Sephadex G-50 columns (Sigma Aldrich, Sweden). Both strands were sequenced with the Big-Dye terminator cycle sequencing kit (PE Applied Biosystems, USA) using the same primers used for the initial amplification.

\section{Phylogenetic analyses}

Contigs were generated from the forward and reverse sequences for each isolate using CLCBio 7.6.1 (Cambridge, Massachusetts). Sequences generated in this study were compared with sequences from GenBank (http://www.ncbi.nlm.nih.gov) using BLASTn (Altschul et al. 1990).

Data matrices for the respective gene regions were compiled in MEGA 5 (Tamura et al. 2011). These included sequences of isolates obtained from mangroves and reference sequences from GenBank. Alignments were done online using MAFFT 7 (Katoh and Standley 2013) under the default setting G-INS-I and ends were trimmed in MEGA 5 (Tamura et al. 2011). All datasets were subjected to Bayesian inference (BI) and maximum likelihood (ML) analyses.

Appropriate substitution models for ML and BI analyses were determined for each of the data sets using the Akaike Information Criterion (AIC) in jModeltest 2.1.4 (Darriba et al. 2012). ML was performed in PhyML 3.0 (Guindon and Gascuel 2003), taking into account the proportion of invariable sites. The Akaike information criterion (AIC) (Sugiura 1978) was used to determine the gamma shape and number of substitution sites (nst), and confidence levels were estimated with 1000 bootstrap replicates. Bayesian analysis was completed for individual data sets using the Markov Chain Monte Carlo (MCMC) algorithms (Larget and Simon 1999), in MrBayes 3.2 (Ronquist et al. 2012). Two independent runs were performed, both of 3 million generations. Four chains were used and trees were sampled every 100th generation. Burn-in values were determined with Tracer 1.4 (Rambaut and Drummond 2007), 
and the first $25 \%$ of sampled trees were discarded. The phylogenetic trees obtained from ML and BI analyses were viewed in MEGA 5 (Tamura et al. 2011) and Treeview (Page 1996).

\section{Morphological characterization}

For the description of novel species, colony morphology and microscopic features were examined from cultures growing on $2 \%$ MEA. Where possible, microscope slides were prepared for the ascomata, conidiophores, and conidia, in $85 \%$ lactic acid. Characters such as size of ascomata, size, shape and pigmentation of ascospores and conidia and the size and pigmentation of conidiophores were used for the description of the novel species. Fifty measurements of the length and width of structures $(1 / \mathrm{w})$ were made for each morphological character and the mean, standard deviation and $95 \%$ confidence intervals were calculated. Minimum and maximum sizes are presented in parentheses as (min-) mean \pm SD $(-\max )$. Morphological observations were made using a Zeiss Axioskop microscope (Carl Zeiss, Germany). Photos of structures were obtained with an Axiocam digital camera (Carl Zeiss, Germany) and fungal structures were measured using the Axiovision 3.1 software (Carl Zeiss, Germany). Taxonomic descriptions and nomenclatural data were deposited in MycoBank (www.MycoBank.org).

\section{Growth in culture and colony characterization}

To determine the colony growth of the new taxon, $5 \mathrm{~mm}$ diam plugs of the ex-holotype culture were placed at the centers of $90 \mathrm{~mm}$ Petri plates containing $2 \%$ MEA. Five replicate plates were incubated in the dark at temperatures ranging from $5{ }^{\circ} \mathrm{C}$ to $35^{\circ} \mathrm{C}$ at $5{ }^{\circ} \mathrm{C}$ intervals for ten days. Diameters of the colonies ( $\mathrm{mm}$ ) were measured after $10 \mathrm{~d}$, along two perpendicular axes centered on the plugs. Average growth was calculated for each of the different temperatures and the experiment was repeated once. The colony color was assessed after three weeks on $2 \%$ MEA, using the color chart of Rayner (1970).

\section{Results}

\section{Fungal isolations}

A total of 60 isolates resembling species of Ophiostoma and Sporothrix were recovered from 80 wounded B. racemosa trees ( $75 \%$ of trees wounded) at the Mapelane Nature Reserve on medium containing cycloheximide. No ophiostomatoid fungi were isolated from any of the other wounded trees. Colonies of fungi obtained from artificially induced wounds on $B$. 
racemosa were cleaned, purified and used for DNA extractions and identification using DNA sequence data.

\section{Fungal Identification}

PCR amplification and sequencing

DNA was extracted from the 60 isolates resembling species of Ophiostomataceae and PCR and sequence products were generated for four gene regions of selected isolates. The sequence fragments were approximately 500-670 bp in size for ITS, 260-340 bp for BT, 330-474 bp for CAL, and 320-400 bp for TEF.

\section{Phylogenetic analyses}

Preliminary analysis of the ITS sequence data for the 60 ophiostomatoid isolates identified the presence of three clades, represented by two genera, Ophiostoma (56 isolates from 56 trees) and Sporothrix (four isolates from four trees). Based on these results selected isolates from B. racemosa were included for posterior phylogenetic analyses of the ITS dataset, comprising 89 sequences from three genera in the Ophiostomatales (Fig. 2), these analyses revealed that the isolates from $B$. racemosa grouped in three distinct lineages belonging to the O. pluriannulatum and O. ulmi complexes in Ophiostoma sensu stricto (Zanzot et al. 2010; De Beer et al. 2013), and Sporothrix (De Beer et al. 2016). Species level identification was confirmed by separate analyses of smaller data sets for the ITS, BT, CAL and TEF gene regions. Forty six representative sequences of isolates recovered in this study were deposited in GenBank (Table 1).

Data sets for the $O$. pluriannulatum complex included 14 taxa for ITS and 11 taxa for BT. As has been shown previously (Zanzot et al. 2010), the ITS region does not provide sufficient resolution to distinguish between closely related species (Fig. 3). The isolates from B. racemosa grouped with an isolate labeled as $O$. pluriannulatum from a Pinus sp. in KwaZulu-Natal (Zhou et al. 2006). The latter isolate was distinct from other isolates of $O$. pluriannulatum from the USA from where this species was first reported (Hedgcock 1906) and, therefore, does not represent that species. The BT region clearly showed that the isolates obtained from B. racemosa were distinct from all the known taxa in the complex (Fig. 3).

Analyses of the three gene regions for species of the O. ulmi complex (Fig. 4) confirmed that isolates obtained in the present study grouped with representative sequences of $O$. tsotsi. The 36 isolates of this species were represented by two haplotypes (HT1 and HT2) in the TEF gene and three haplotypes (HT3, HT4 and HT5) in the BT gene. This 


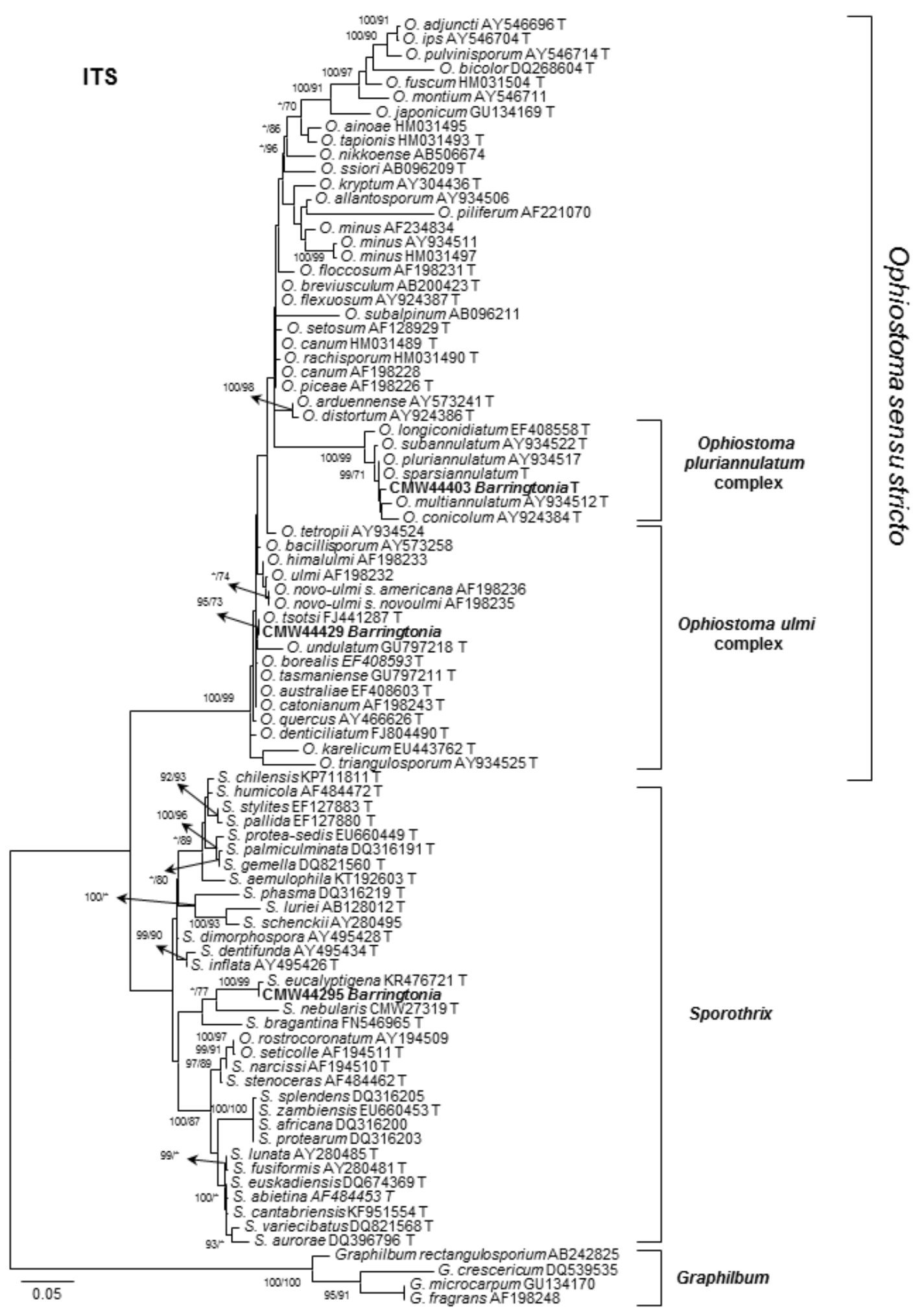

Fig. 2 Phylogram obtained from BI and ML analyses of the ITS data set. Isolates from mangroves group into the Ophiostoma pluriannulatum complex, Ophiostoma ulmi complex and Sporothrix. Isolates obtained in this study are printed in bold and the equivalent genus names are presented next to the brackets. The ex-type isolate of each species is indicated by T. BI posterior probabilities $\geq 90 \%$ are represented by thick branches. Bootstrap support values $>70 \%$ are indicated near the nodes. $*$ = bootstrap support values $<70 \%$. 
Table 1 Ophiostomatales isolates used in the present study, isolated from wounds of Barringtonia racemosa (mangrove associate) in Mapelane Nature Reserve

\begin{tabular}{|c|c|c|c|c|c|}
\hline \multirow[t]{2}{*}{ Fungal species } & \multirow[t]{2}{*}{ Number } & \multicolumn{4}{|c|}{ Gene regions } \\
\hline & & ITS & TEF & BT & CAL \\
\hline Ophiostoma palustre sp. nov. & CMW44403 (Туре) & KU865593 & $*$ & KX273409 & $*$ \\
\hline O. palustre sp. nov. & CMW44408 (Paratype) & KU865595 & $*$ & KX273410 & $*$ \\
\hline O. palustre sp. nov. & CMW44400 & KU865594 & $*$ & $\mathrm{KX} 273412$ & $*$ \\
\hline O. palustre sp. nov. & CMW44396 & KU865596 & $*$ & KX273411 & $*$ \\
\hline O. tsotsi & CMW44387 & KU865603 & KX273413 & KX273398 & $*$ \\
\hline O. tsotsi & CMW44409 & KU865599 & KX273415 & KX273400 & $*$ \\
\hline O. tsotsi & CMW44414 & KU865608 & KX273422 & KX273405 & $*$ \\
\hline O. tsotsi & CMW44420 & KU865615 & KX273424 & KX273406 & $*$ \\
\hline O. tsotsi & CMW44421 & KU865597 & KX273425 & $\mathrm{KX} 273407$ & $*$ \\
\hline O. tsotsi & CMW44429 & KU865628 & KX273417 & KX273401 & $*$ \\
\hline O. tsotsi & CMW44430 & KU865629 & KX273418 & KX273402 & $*$ \\
\hline O. tsotsi & CMW44431 & KU865630 & KX273419 & KX273403 & $*$ \\
\hline O. tsotsi & CMW44432 & KU865631 & KX273420 & KX273404 & $*$ \\
\hline O. tsotsi & CMW44433 & KU865609 & KX290459 & KX273408 & $*$ \\
\hline O. tsotsi & CMW44297 & KU865611 & KX273421 & $*$ & $*$ \\
\hline O. tsotsi & CMW44392 & KU865610 & KX273414 & $*$ & $*$ \\
\hline O. tsotsi & CMW44410 & KU865601 & KX273416 & $*$ & $*$ \\
\hline O. tsotsi & CMW44416 & KU865612 & $\mathrm{KX} 273423$ & $*$ & $*$ \\
\hline O. tsotsi & CMW44296 & KU865625 & $*$ & KX273397 & $*$ \\
\hline O. tsotsi & CMW44390 & KU865606 & $*$ & KX273399 & $*$ \\
\hline O. tsotsi & CMW44391 & KU865598 & $*$ & KX273396 & $*$ \\
\hline O. tsotsi & CMW44402 & KU865600 & $*$ & $*$ & $*$ \\
\hline O. tsotsi & CMW44385 & KU865602 & $*$ & $*$ & $*$ \\
\hline O. tsotsi & CMW44415 & KU865617 & $*$ & $*$ & $*$ \\
\hline O. tsotsi & CMW44388 & KU865604 & $*$ & $*$ & $*$ \\
\hline
\end{tabular}




\begin{tabular}{|c|c|c|c|c|c|}
\hline O.tsotsi & CMW44389 & KU865605 & $*$ & $*$ & $*$ \\
\hline O. tsotsi & CMW44393 & KU865619 & $*$ & $*$ & $*$ \\
\hline O. tsotsi & CMW44394 & KU865621 & $*$ & $*$ & $*$ \\
\hline O. tsotsi & CMW44397 & KU865622 & $*$ & $*$ & $*$ \\
\hline O. tsotsi & CMW44404 & KU865627 & $*$ & $*$ & $*$ \\
\hline O. tsotsi & CMW44405 & KU865632 & $*$ & $*$ & $*$ \\
\hline O. tsotsi & CMW44406 & KU865620 & $*$ & $*$ & $*$ \\
\hline O. tsotsi & CMW44413 & KU865607 & $*$ & $*$ & $*$ \\
\hline O. tsotsi & CMW44417 & KU865614 & $*$ & $*$ & $*$ \\
\hline O. tsotsi & CMW44418 & KU865613 & $*$ & $*$ & $*$ \\
\hline O. tsotsi & CMW44419 & KU865616 & $*$ & $*$ & $*$ \\
\hline O. tsotsi & CMW44422 & KU865618 & $*$ & $*$ & $*$ \\
\hline O. tsotsi & CMW44424 & KU865623 & $*$ & $*$ & $*$ \\
\hline O.tsotsi & CMW44426 & KU865626 & $*$ & $*$ & $*$ \\
\hline O. tsotsi & CMW44434 & KU865624 & $*$ & $*$ & $*$ \\
\hline Sporothrix eucalyptigena & CBS139899 (Type) & KR476721 & $*$ & KX273395 & KX273431 \\
\hline S. eucalyptigena & CMW44295 & KU865588 & $*$ & KX273390 & KX273426 \\
\hline S. eucalyptigena & CMW44399 & KU865592 & $*$ & KX273394 & KX273427 \\
\hline S. eucalyptigena & CMW45046 & KU865589 & $*$ & KX273391 & KX273428 \\
\hline S. eucalyptigena & CMW45047 & KU865590 & $*$ & KX273392 & KX273429 \\
\hline S. eucalyptigena & CMW45048 & KU865591 & $*$ & KX273393 & KX273430 \\
\hline
\end{tabular}

Legend: * = Isolate not included in the phylogenetic analyses (depending of the gene region).

$\mathrm{CMW}=$ culture collection of the Tree Protection Co-operative Programme (TPCP) at FABI, University of Pretoria 

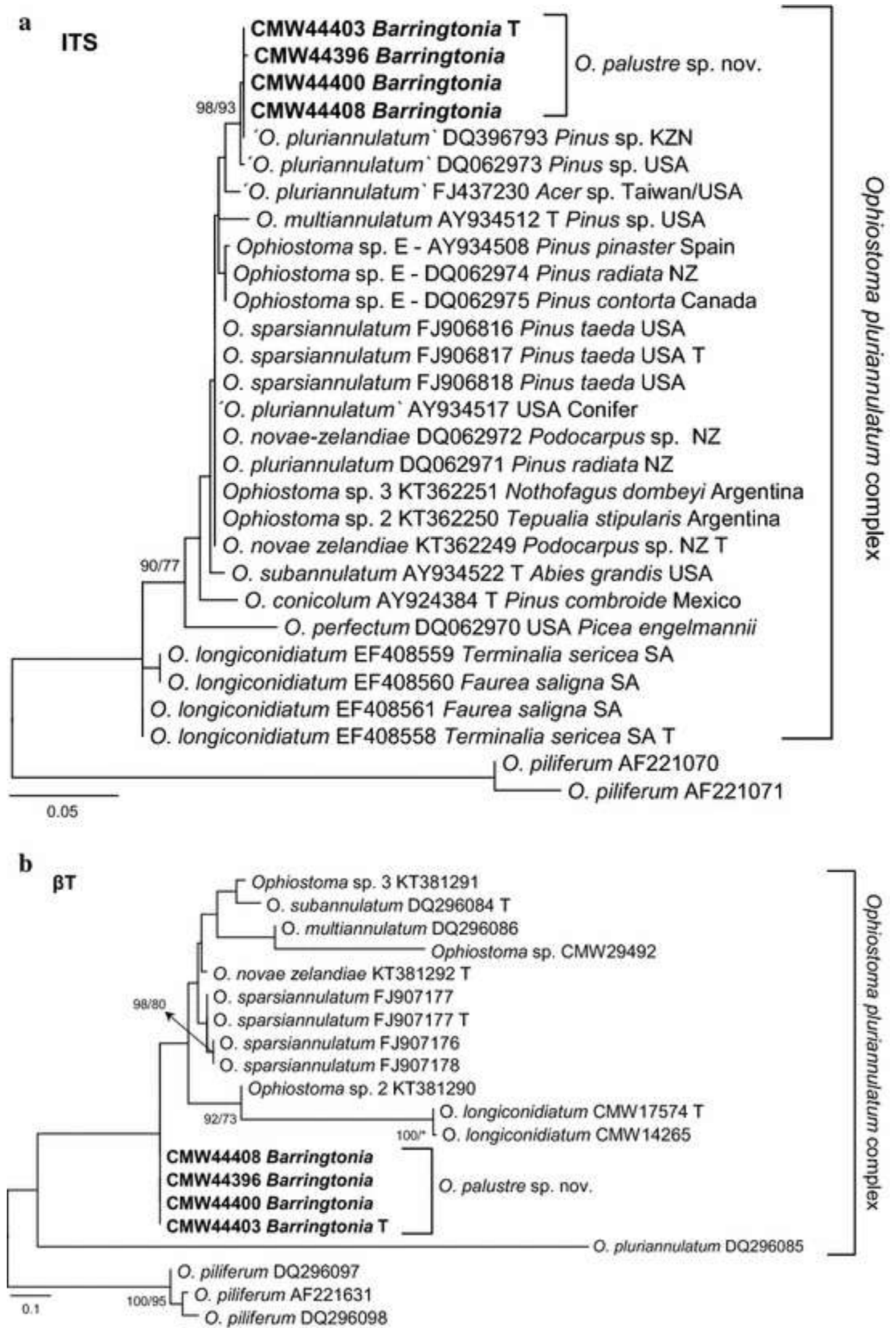

Fig. 3 Phylogram of species in the Ophiostoma pluriannulatum complex obtained from BI and ML analyses of the ITS and BT gene region. The isolates from mangroves (in bold) form a different clade in the BT gene region. The ex-type isolate of each species is indicated by $\mathrm{T}$. BI posterior probabilities $\geq 90 \%$ and Bootstrap support values $>70 \%$ are indicated near the nodes as BI/ML. * = bootstrap support values $<70 \%$. 

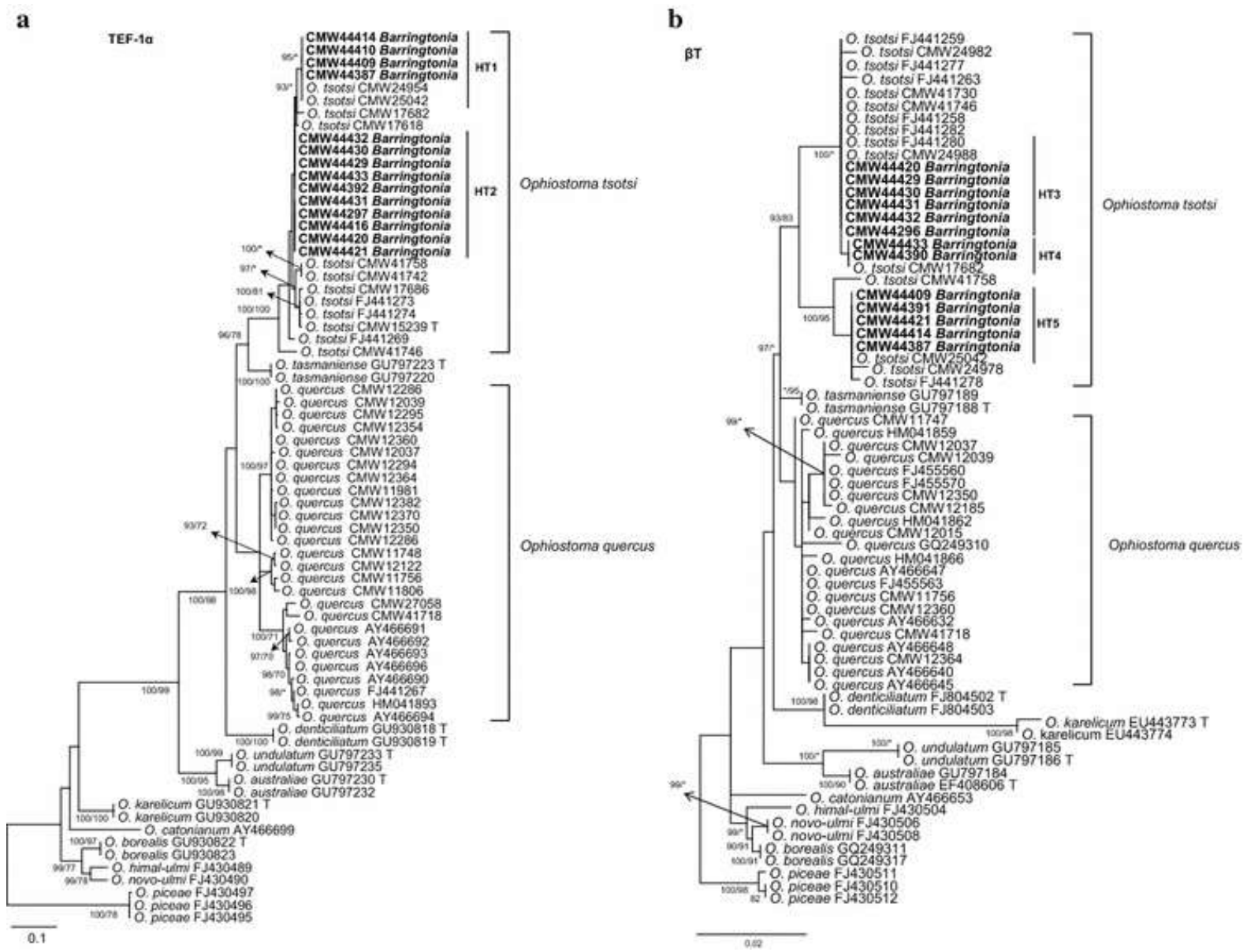

Fig. 4 Phylogram of species in the Ophiostoma ulmi complex from BI and ML analyses of the TEF and BT gene regions. The isolates obtained from mangroves (in bold) group with different haplotypes (HT) of Ophiostoma tsotsi. The ex-type isolate of each species is indicated by T. BI posterior probabilities (PP) $\geq 90 \%$ and Bootstrap support values $(\mathrm{BS})>70 \%$ are indicated near the nodes as BI/ML. $*=\mathrm{PP}<90$.

species is known to be genetically variable (Kamgan et al. 2012), but strong support values provided robust evidence that the variable haplotypes represent a single taxon (Fig. 4).

The third group of isolates belonged to Sporothrix. ITS, BT and CAL sequences (Fig. 5) were identical to those of the ex-type isolate of S. eucalyptigena, recently described from Eucalyptus in Australia (Crous et al. 2015). 

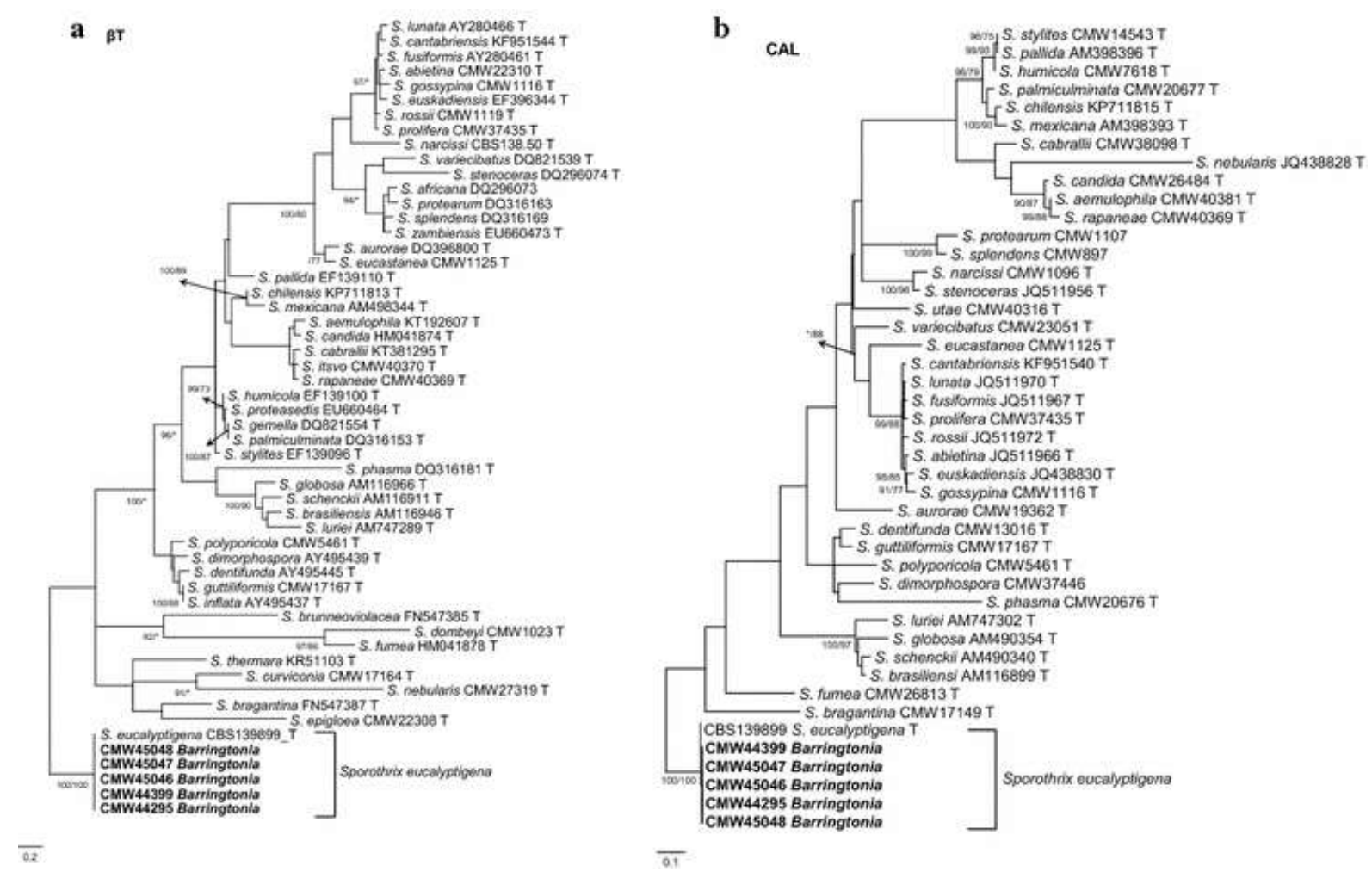

Fig. 5 Phylogram of Sporothrix species from BI and ML analyses of the BT and CAL gene regions. The isolates obtained from mangroves (in bold) group consistently with Sporothrix eucalyptigena. The ex-type isolate of each species is indicated by T. BI posterior probabilities $\geq 90 \%$ and Bootstrap support values $>70 \%$ are indicated near the nodes as BI/ML. * $=\mathrm{PP}<90 \%$ and $\mathrm{BS}$ support values $<70 \%$.

\section{Taxonomy}

Based on comparisons of multigene sequence data, a new taxon in the Ophiostomatales was found to be associated with B. racemosa in South Africa. Both sexual and asexual stages were observed and these are included in the following description:

Ophiostoma palustre sp. nov. J.A Osorio, Z. W. de Beer \& Jol. Roux (Fig. 6) MycoBank: MB815732

Etymology: Epithet refers to the areas (swamp, marsh) where the host occurs.

Sexual state: Ascomata forming in concentric rings on MEA. Ascomatal necks cylindrical, dark brown, (285-)433-568(-923) $\mu \mathrm{m}$ long, (12-)20-24.5(-29.5) $\mu \mathrm{m}$ wide. Ostiolar hyphae hyaline, slightly divergent. Ascomatal bases dark brown with ornamental hyphae, (100-)118142(186) $\mu \mathrm{m}$ high, (107-)130-151(-185) $\mu \mathrm{m}$ wide at middle. Ascospores somewhat allantoid, hyaline, smooth, unicellular, (3.4-)4.7-5(-6.1) ×(1.3)1.5-1.6(-1.9) $\mu \mathrm{m}$. 


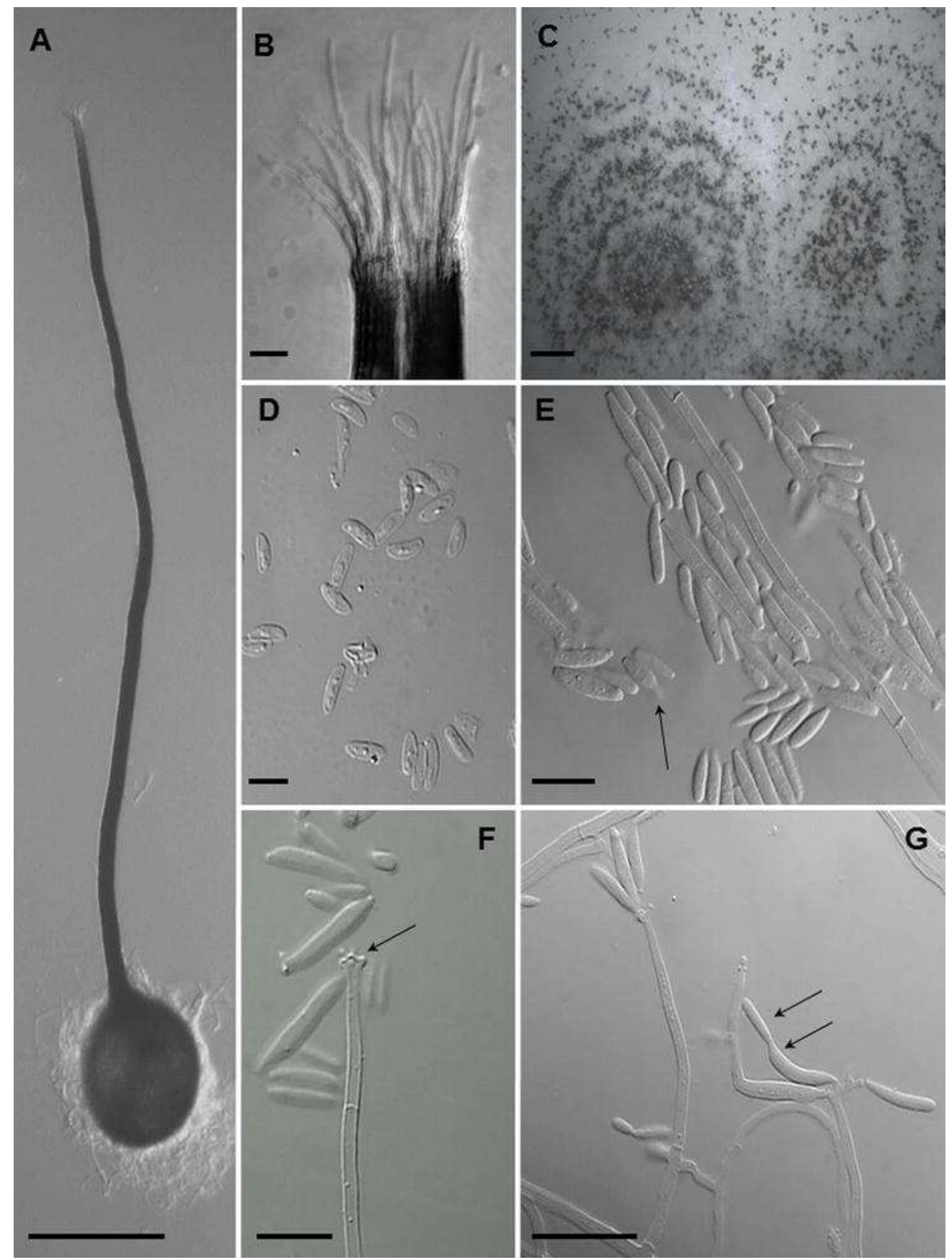

Fig. 6 Ophiostoma palustre sp. nov. (Ex-holotype CMW44403). (A-D) Sexual structures. (A) Ascoma, (B) ostiolar hyphae, (C) Formation of concentric rings of ascomata on MEA agar, (D) ascospores. (E-G) Asexual structures. (E) Hyaline conidia, primary conidia (arrow), (F) development of conidia, conidiophore with denticles on apex (arrow). (G) Development of primary and secondary conidia. $A=50 \mu \mathrm{m}, \mathrm{B}=10 \mu \mathrm{m}, \mathrm{C}=2 \mathrm{~mm}$, $\mathrm{D}=5 \mu \mathrm{m}, \mathrm{E}=20 \mu \mathrm{m}, \mathrm{F}=10 \mu \mathrm{m}, \mathrm{G}=20 \mu \mathrm{m}$. 
Asexual state: Conidiophores mononematous, micronematous, hyaline, sometimes 1-2 septate, (32-)23-100(-110) $\mu \mathrm{m}$ long, (2-)1.7-2.3(-2.3) $\mu \mathrm{m}$ wide, denticulate forming up to 5 denticles giving rise to ramoconidia. Primary conidia septate, hyaline, truncate base, $(10-$ )14-16.5(-23) $\times(2-) 2.4-2.6(-3.3) \mu \mathrm{m}$, giving rise to secondary conidia. Secondary conidia obclavate, obtuse base, aseptate, smooth, thin walled, (4.3-)5-6(-7.5) × (1.4-) 1.7-2(-2.4) $\mu \mathrm{m}$.

Culture characteristics: Colonies on MEA at $25^{\circ} \mathrm{C}$ in darkness after three weeks, with dense cottony mycelium around the plug, white at first, becoming white opaque, reverse side the same, flattened mycelium towards the edges, smooth margin, concentric rings formed by ascomata. Cardinal temperatures for growth: minimum $\leq 20^{\circ} \mathrm{C}$, maximum $\geq 35^{\circ} \mathrm{C}$, optimum $25{ }^{\circ} \mathrm{C}$. Colonies reaching an average of $22 \mathrm{~mm}$ at $20{ }^{\circ} \mathrm{C}, 33 \mathrm{~mm}$ at $25^{\circ} \mathrm{C}, 32 \mathrm{~mm}$ at $30{ }^{\circ} \mathrm{C}, 5$ mm at $35{ }^{\circ} \mathrm{C}$, no growth at $5{ }^{\circ} \mathrm{C}, 10{ }^{\circ} \mathrm{C}$ and $15^{\circ} \mathrm{C}$ after 10 days.

Specimens examined: SOUTH AFRICA, KWAZULU-NATAL PROVINCE: Mapelane, isolated from wounds on the stem of Barringtonia racemosa, collector J.A Osorio, June 2014. Holotype (PREM 61291, ex-holotype CMW44403 = CBS140596); Paratype (PREM 61292, ex-paratype CMW44408 = CBS140597, CMW44400 = CBS140598). Additional specimen (CMW44396).

Habitat: Artificially induced wounds on stems of Barringtonia racemosa.

Known distribution in South Africa: Mapelane Nature Reserve (KwaZulu-Natal Province, South Africa).

\section{Discussion}

This study represents the first attempt to systematically survey for the presence of ophiostomatoid fungi associated with mangrove trees. No ophiostomatoid fungi were obtained from wounds on the true mangrove species included in the study. However, two species of Ophiostoma and one of Sporothrix were isolated from wounded trees of the mangrove associate, Barringtonia racemosa. Of these, one fungus represented a novel species for which the name Ophiostoma palustre has been provided. The two other species, Ophiostoma tsotsi and Sporothrix eucalyptigena, have been described previously and require no further treatment.

Ophiostoma palustre sp. nov. forms part of the O. pluriannulatum complex. The species complex was first introduced as the $O$. multiannulatum complex by Villarreal et al. 
(2005), but Zanzot et al. (2010) suggested that it is more appropriate to refer to the complex by the name of the species that was first described, namely $O$. pluriannulatum (Hedgcock 1906). Most species in the complex are characterized by long ascomatal necks that often, but not always, produce irregular numbers of annuli (Zanzot et al. 2010; De Beer and Wingfield 2013). To date only ITS and BT data have been used to delineate species in the complex (Zanzot et al. 2010; De Errasti et al. 2016). Based on these studies and our analyses, it is clear that the complex includes several undescribed taxa, some of which have been inappropriately referred to as 'O. pluriannulatum' (e.g. Thwaites et al. 2005; Zhou et al. 2006). Some species have been isolated from conifer hosts, such as O. multiannulatum from pines in the USA (Davidson 1935), 'Ophiostoma sp. E’ from pines in Canada, New Zealand and Spain (Thwaites et al. 2005, Villareal et al. 2005), and O. novae-zelandiae from Podocarpus in New Zealand (Hutchison and Reid 1988; De Errasti et al. 2016). However, several other species are associated with hardwoods, including the original report of $O$. pluriannulatum from Quercus in the USA (Hedgcock 1906), O. longiconidiatum from Faurea saligna and Terminalia sericea in South Africa (Kamgan et al. 2008), as well as O. novae-zelandiae and two undescribed taxa from Nothofagus dombeyi and Tepualia stipularis in Argentina (De Errasti et al. 2016). None of these species have been associated with tree disease. Although some of them have been reported as wound-infecting (Kamgan et al. 2008) and sap stain fungi, the stain seems to be superficial and not causing significant damage (Davidson 1935, Thwaites et al. 2005).

The phylogenetic placement of $O$. palustre in the $O$. pluriannulatum complex is supported by its long-necked ascomata forming concentric circles in culture, ascospore shape and denticulate conidiogenous cells on mycelial conidiophores. Furthermore, its association with wounds on hardwood trees corresponds with the biology of other species in the complex. The fact that another species, $O$. longiconidiatum, has been found only on native South African trees (Kamgan et al. 2008), suggests that new species in this complex remain to be discovered in South Africa. Because the O. pluriannulatum complex does not include any known tree pathogens, it can be assumed that $O$. palustre also does not pose a threat to the health of B. racemosa trees. However, pathogenicity studies should be performed to consider the possible role of $O$. palustre in disease development.

The most prevalent fungus isolated from wounds of B. racemosa was Ophiostoma tsotsi. This species forms part of $O$. ulmi complex, a fungal group that was previously treated as part of the $O$. piceae complex (Grobbelaar et al. 2009, Harrington et al. 2001). However, De Beer and Wingfield (2013) showed that the so-called 'hardwood clade' of the $O$. piceae 
complex represents a well-supported lineage distinct from the conifer isolates and referred to it as the O. ulmi complex. Similarly, Yin et al. (2016) distinguished between the O. ulmi complex and a newly defined $O$. piceae complex that includes only conifer-associated fungi. Grobbelaar et al. (2010) showed that BT and EF sequences are needed in addition to ITS to resolve species level questions in the $O$. ulmi complex. Our analyses of these three gene regions (Fig. 4) supported the outcomes of previous studies (Grobbelaar et al. 2009, 2010; Kamgan et al. 2010, 2012) showing that $O$. tsotsi, similar to O. quercus, is genetically highly variable.

The discovery of $O$. tsotsi on wounds of Barringtonia racemosa in Mapelane is interesting. This is in view of the fact that the fungus has previously been reported from the Kwambonambi area, about $25 \mathrm{~km}$ from Mapelane. Kamgan et al. (2012) isolated O. tsotsi from wounds on Eucalyptus trees grown commercially in the area, as well as from two nitidulid species, Brachypeplus depressus and Carpophilus humeralis, found visiting these wounds. Ophiostoma tsotsi has also been reported from Acacia mearnsii and other Eucalyptus species elsewhere in South Africa (Grobbelaar et al. 2010; Kamgan et al. 2012), and from wounds on the same or similar hardwood hosts in Malawi, Uganda (Grobbelaar et al. 2010), China, Vietnam (Grobbelaar et al. 2011) and Australia (Kamgan et al. 2011).

Although the O. ulmi complex includes Ophiostoma ulmi and O. novo-ulmi, the causal agents of the Dutch elm disease (Brasier 1991), most species in the complex, including O. tsotsi, are known as non-pathogenic sapstain fungi on hardwood trees (Seifert et al. 1993; De Beer et al. 2003; Grobbelaar et al. 2010). Inoculation studies with $O$. tsotsi on young Eucalyptus trees showed no signs of pathogenicity (Kamgan et al. 2011), suggesting that the fungus is most probably an opportunistic colonizer of the sapwood on these trees when introduced by non-host specific nitidulid vectors attracted to freshly exposed wounds.

Sporothrix eucalyptigena (= Ophiostoma eucalyptigena), found in this study residing in Sporothrix, as recently revised by De Beer et al. (2016), was first described from a single isolate obtained from Eucalyptus marginata in Australia (Crous et al. 2015). There is unfortunately no information regarding the biology or ecology of the species. It is remarkable that, similar to $O$. tsotsi and S. eucalyptigena, it was found on B. racemosa growing adjacent to vast commercially propagated plantations of Eucalyptus. It would be interesting to sample the Eucalyptus plantations in the coastal planes of KwaZulu-Natal more extensively to ascertain whether the fungus also occurs on these trees in South Africa.

The apparent absence of ophiostomatoid fungi on true mangroves was surprising but might be explained by the ecology of these trees. True mangrove species are considered 
halophytic and can thrive in salt rich environments, while mangrove associates are mostly categorized as glycophytes with a certain tolerance to salt (Tomlinson 1986; Wang et al. 2010). Salinity levels can restrict fungal growth, hence the mycobiota in such environments require specific adaptations for salt tolerance in order to proliferate successfully (Gilbert et al. 2002; Cantrell et al. 2011). The three true mangrove species surveyed in the present study grow in saline environments. However, the mangrove associate, $B$. racemosa, from which the three Ophiostomatales species were isolated, grow mostly in swamp areas with fresh water flow. A possible explanation for the absence of these fungi on the true mangroves and their presence on $B$. racemosa might lie in the physiochemical difference between halophytes and glycophytes. It is likely that certain groups of fungi such as the ophiostomatoid fungi may not be able to survive in the high saline ecosystems where true mangroves occur. Further studies are required to determine whether the absence of ophiostomatoid fungi is determined by abiotic factors such as salinity, or by the physiological characteristic of the hosts.

The overall results of this study have shown that ophiostomatoid fungi are rare inhabitants of mangrove environments, and they suggest that these fungi do not pose a threat to these trees in South Africa. However, as the mangrove ecosystems are impacted by environmental changes, periodic monitoring to assess the presence of ophiostomatoid fungi and other potential pathogens, also those associated with invasive bark and ambrosia beetles is recommended.

\section{Acknowledgments}

This work was financially supported by the Department of Science and Technology (DST) and National Research Foundation (NRF) Center of Excellence in Tree Health Biotechnology (CTHB). We thank Ezemvelo KZN Wildlife (EKZNW), the Isimangaliso Wetland Park and the Eastern Cape Parks \& Tourism Agency (ECPTA) for sampling permits as well as their members for assistance in the field. The material was collected under EKZNW permits No. OP 4776, OP 1457 and the ECPTA - RA 00119. We gratefully acknowledge Dr. Hugh Glen for assistance in providing an appropriate species name for the novel taxon. We also acknowledge the fellow post-graduate students at the Forestry and Agricultural Biotechnology Institute (FABI), University of Pretoria and Dr. Riikka Linakoski (University of Helsinki) for their help during the field work. 


\section{References}

Adams JB, Colloty BM, Bate GC (2004) The distribution and state of mangroves along the coast of Transkei, Eastern Cape Province, South Africa. Wetl Ecol Manag 12:531 541

Alongi DM (2002) Present state and future of the world's mangrove forests. Environ Conserv 29:331-349

Altschul SF, Gish W, Miller W, Myers EW, Lipman DJ (1990) Basic local alignment search tool. J Mol Biol 215:403-410

Brasier CM (1991) Ophiostoma novo-ulmi sp. nov., causative agent of current Dutch elm disease pandemics. Mycopathologia 115:151-161

Brasier CM (2000) Intercontinental spread and continuing evolution of the Dutch elm disease pathogens. In: Dunn CP (ed). The Elms: Breeding, Conservation, and Disease Management. Kluwer Academic Publishers, Boston, USA, pp 61-72

Cantrell SA, Dianese JC, Fell J, Gunde-Cimerman, Zalar P (2011) Unusual fungal niches. Mycologia 103:1161-1174

Crous PW, Wingfield MJ, Guarro J, Hernandez-Restrepo M, Sutton DA, Acharya K, Barber PA, Boekhout T, Dimitrov RA, Dueñas M, Dutta AK (2015) Ophiostoma eucalyptigena Barber \& Crous, sp. nov. Fungal planet description sheets: 331. Persoonia 34:192-193

Darriba D, Taboada G, Doallo R, Posada D (2012) jModelTest 2: more models, new heuristics and parallel computing. Nature Methods 9:772

Davidson RW (1935) Fungi causing stain in logs and lumber in the Southern States, including five new species. J Agric Res 50:789-807

De Beer ZW, Wingfield BD, Wingfield MJ (2003) The Ophiostoma piceae complex in the Southern Hemisphere: a phylogenetic study. Mycol Res 107:469-76

De Beer ZW, Seifert KA, Wingfield MJ (2013) The ophiostomatoid fungi: their dual position in the Sordariomycetes. In: Seifert KA, De Beer ZW, Wingfield MJ (eds) The Ophiostomatoid fungi: expanding frontiers. CBS Biodiversity Series 12. CBS Fungal Diversity Centre, Utrecht, pp 1-19

De Beer ZW, Wingfield MJ (2013) Emerging lineages in the Ophiostomatales. In: Seifert KA, De Beer ZW, Wingfield MJ (eds) The Ophiostomatoid Fungi: Expanding Frontiers. CBS, Utrecht, The Netherlands, pp 21-46 
De Beer ZW, Duong TA, Wingfield MJ (2016) The divorce of Sporothrix and Ophiostoma: solution to a problematic relationship. Studies in Mycology doi:10.1016/j.simyco.2016.07.001

De Errasti A, de Beer ZW, Coetzee MPA, Roux J, Rajchenberg M, Wingfield MJ (2016) Three new species of Ophiostomatales from Nothofagus in Patagonia. Mycol Prog $15: 1-15$

Duke NC, Meynecke JO, Dittmann S, Ellison AM, Anger K, Berger U, Cannicci S, Diele K, Ewel KC, Field CD, Koedam, N, Lee SY, Marchand C, Nordhaus I, Dahdouh-Guebas F (2007) A world without mangroves?. Science 317:41-42

Duong TA, de Beer ZW, Wingfield BD, Wingfield MJ (2012) Phylogeny and taxonomy of species in the Grosmannia serpens complex. Mycologia 104:715-732

Fraedrich SW, Harrington TC, Rabaglia RJ, Ulyshen MD, Mayfield AE, Hanula JL, Eickwort JM, Miller DR (2008) A fungal symbiont of the redbay ambrosia beetle causes a lethal wilt in redbay and other Lauraceae in the southeastern United States. Plant Dis 92:215-224

Gardes M, Bruns TD (1993) ITS primers with enhanced specificity for Basidiomycetes applications to the identification of mycorrhizae and rusts. Mol Ecol 2:113-118

Geldenhuis MM, Roux J, Montenegro F, de Beer ZW, Wingfield MJ, Wingfield BD (2004) Identification and pathogenicity of Graphium and Pesotum species from machete wounds on Schizolobium parahybum in Ecuador. Fungal Divers 15:135-149

Gibbs JN (1993) The biology of ophiostomatoid fungi causing sapstain in trees and freshly cut logs. In: Wingfield MJ, Seifert KA, Webber JF (eds) Ceratocystis and Ophiostoma: taxonomy, ecology and pathogenicity. APS Press, St. Paul, pp 153-160

Gilbert GS, Mejía M, Rojas E (2002) Fungal diversity and plant disease in mangrove forests: salt excretion as a possible defense mechanism. Oecologia 132:278-285

Glass NL, Donaldson GC (1995) Development of primer sets designed for use with the PCR to amplify conserved genes from filamentous ascomycetes. Appl Environ Microbiol 61:1323-1330

Grobbelaar JW, Aghayeva D, de Beer ZW, Bloomer P, Wingfield MJ, Wingfield BD (2009) Delimitation of Ophiostoma quercus and its synonyms using multiple gene phylogenies. Mycol Prog 8:221-236

Grobbelaar JW, de Beer ZW, Bloomer P, Wingfield MJ, Wingfield BD (2010) Ophiostoma tsotsi sp. nov., A wound-infesting fungus of hardwood trees in Africa. Mycopathologia 169:413-423 
Grobbelaar JW, de Beer ZW, Bloomer P, Wingfield MJ, Zhou XD, Wingfield BD (2011) Discovery of Ophiostoma tsotsi on Eucalyptus wood chips in China. Mycoscience 52:111-118

Guindon S, Gascuel O (2003) A simple, fast and accurate method to estimate large phylogenies by maximum-likelihood. Syst Biol 52:696-704

Harrington TC (1981) Cycloheximide sensitivity as a taxonomic character in Ceratocystis. Mycologia 73:1123-1129

Harrington TC, Cobb FW Jr (1988) Leptographium root diseases on conifers. American Phytopathological Society Press, St. Paul, Minnesota, USA, 149 p

Harrington TC, McNew D, Steimel J, Hofstra D, Farrell R (2001) Phylogeny and taxonomy of the Ophiostoma piceae complex and the Dutch Elm Disease fungi. Mycologia 93:111-136.

Harrington TC (2005) Ecology and evolution of mycophagous bark beetles and their fungal partners. In: Vega FE, Blackwell M (eds) Insect-Fungal Associations: Ecology and Evolution. Oxford University Press, Inc. New York, USA, pp 257-292

Harrington TC, Aghayeva DN, Fraedrich SW (2010) New combinations in Raffaelea, Ambrosiella, and Hyalorhinocladiella, and four new species from the Redbay ambrosia beetle, Xyleborus glabratus. Mycotaxon 111:337-361

Hayslett M, Juzwik J, Moltzan B (2008) Three Colopterus beetle species carry the oak wilt fungus to fresh wounds on red oak in Missouri. Plant Dis 92: 270-275

Hedgcock GG (1906) Studies upon some chromogenic fungi which discolor wood. Missouri Botanical Garden Annual Report 17:59-114

Henry BW, Moses CS, Richards CA, Riker AJ (1944) Oak wilt, its significance, symptoms and cause. Phytopathology 34:636-647

Hutchison LJ, Reid J (1988) Taxonomy of some potential wood-staining fungi from New Zealand. 1. Ophiostomataceae. N Z J Bot 26:63-81

Jacobs K, Wingfield MJ (2001) Leptographium Species: Tree pathogens, Insect associates and Agents of blue-stain. The American Phytopathological Society Press, St. Paul, Minnesota, USA, $224 \mathrm{p}$

Jacobs K, Bergdahl DR, Wingfield MJ, Halik S, Seifert KA, Bright DE, Wingfield BD (2004) Leptographium wingfieldii introduced into North America and found associated with exotic Tomicus piniperda and native bark beetles. Mycol Res $108: 411-418$ 
Juzwik L, Cease KR, Meyer IM (1998) Acquisition of Ophiostoma quercus and Ceratocystis fagacearum by Nitidulids from O. quercus-colonized oak wilt mats. Plant Dis 82:239-243

Juzwik J, Harrington TC, McDonald WL (2008) The origin of Ceratocystis fagacearum, the Oak Wilt Fungus. Annu Rev Phytopathol 46:13-26

Kamgan NG, Jacobs K, de Beer ZW, Wingfield MJ, Roux J (2008) Ceratocystis and Ophiostoma species including three new taxa, associated with wounds on native South African trees. Fungal Divers 29:37-59

Kamgan NG, Solheim H, de Beer ZW, Grobbelaar JW, Jacobs K, Wingfield MJ, Roux J (2010) Ophiostoma species, including Ophiostoma borealis sp. nov., infecting wounds of native broad-leaved trees in Norway. Cryptogam Mycol 31:285-303 Kamgan NG, de Beer ZW, Wingfield MJ, Mohammed C, Carnegie AJ, Pegg GS, Roux J (2011) Ophiostoma species (Ophiostomatales, Ascomycota), including two new taxa on eucalypts in Australia. Austral J Bot 59:283-297

Kamgan NG, de Beer ZW, Wingfield MJ, Roux J (2012) A diverse assemblage of Ophiostoma species, including two new taxa on eucalypt trees in South Africa. Mycol Prog 11:515-533

Katoh K, Standley DM (2013) MAFFT Multiple sequence alignment software version 7: improvements in performance and usability. Mol Biol Evol 30:772-780

Kile GA (1993) Plant diseases caused by species of Ceratocystis sensu stricto and Chalara.

In: Wingfield MJ, Seifert KA, Webber JF (eds) Ceratocystis and Ophiostoma: taxonomy, ecology and pathogenicity. APS Press, St. Paul, pp 173-183

Kirisits T (2004) Fungal associates of European bark beetles with special emphasis on the ophiostomatoid fungi. In: Lieutier F, Day KR, Battisti A, Grégoire JC, Evans HF (eds) Bark and wood boring insects in living trees in Europe, a synthesis. Kluwer Academic Press, The Netherlands, pp 181-235

Klepzig KD, Six DL (2004) Bark beetle-fungal symbiosis: context dependency in complex associations. Symbiosis 37:189-205.

Kubono T, Ito S (2002) Raffaelea quercivora sp. nov. associated with mass mortality of Japanese oak, and the ambrosia beetle (Platypus quercivorus). Mycoscience 43:255260

Larget B, Simon DL (1999) Markov chain Monte Carlo algorithms for the Bayesian analysis of phylogenetic trees. Mol Biol Evol 16:750-759 
Malloch D, Blackwell M (1993) Dispersal biology of the ophiostomatoid fungi. In: Wingfield MJ, Seifert KA, JF Webber (eds) Ceratocystis and Ophiostoma: taxonomy, ecology and pathogenicity. American Phytopathological Society Press, St. Paul, Minnesota, USA, pp 195-206

Nagelkerken I, Blaber SJM, Bouillon S, Green P, Haywood M, Kirton LG, Meynecke JO, Pawlik J, Penrose HM, Sasekumar A, Somerfield PJ (2008) The habitat function of mangroves for terrestrial and marine fauna: a review. Aquat Bot 89:155-185

Osorio JA, Wingfield MJ, de Beer ZW, Roux J (2015) Pseudocercospora mapelanensis sp. nov., associated with a fruit and leaf disease of Barringtonia racemosa in South Africa. Australas. Plant Pathol 44:349-359

Page RD (1996) TREEVIEW: an application to display phylogenetic trees on personal computers. Comput Appl Biosci 12:357-358

Raeder U, Broda P (1985) Rapid preparation of DNA from filamentous fungi. Lett Appl Microbiol 1:17-20

Rajkaran A, Adams J, Taylor R (2009) Historic and recent (2006) state of mangroves in small estuaries from Mlalazi to Mtamvuna in KwaZulu-Natal, South Africa. South Forests 7:287-296

Rambaut A, Drummond AJ (2007) Tracer 1.4. Available at http://beast.bio.ed.ac.uk/Tracer Rayner, RW (1970) A mycological colour chart. Kew, Surrey, UK: CMI and British Mycological Society

Ronquist F, Teslenko M, van der Mark P, Ayres DL, Darling A, et al. (2012) MrBayes 3.2: efficient Bayesian phylogenetic inference and model choice across a large model space. Syst Biolo 61:539-542

Roux J, Dunlop R, Wingfield MJ (1999) Susceptibility of elite Acacia mearnsii families to Ceratocystis wilt in South Africa. J For Res 4:187-190

Roux J, Van Wyk M, Hatting H, Wingfield MJ (2004) Ceratocystis species infecting stem wounds on Eucalyptus grandis in South Africa. Plant Pathol 53:414-421

Roux J, Heath RN, Labuschagne L, Kamgan Nkuekam K, Wingfield MJ (2007) Occurrence of the wattle wilt pathogen, Ceratocystis albifundus on native South African trees. Forest Pathol 37:292-302

Roux J, Wingfield MJ (2009) Ceratocystis species: emerging pathogens of non-native plantation Eucalyptus and Acacia species. South Forests 7:115-120

Seifert KA, Wingfield MJ, Kendrick WB (1993) Sapstain of commercial lumber by species of Ophiostoma and Ceratocystis. In: Wingfield MJ, Seifert KA, Webber J, (eds) 
Ceratocystis and Ophiostoma: taxonomy, ecology and pathogenicity. St. Paul, Minnesota, USA, pp 141-151

Seifert KA, de Beer ZW, Wingfield MJ (2013) The ophiostomatoid fungi: expanding frontiers. CBS-KNAW Fungal Biodiversity Centre 337 p

Sinclair WA, Howard HL (2005) Diseases of trees and shrubs. Ed. 2. Comstock Publishing Associates, Ithaca, London: Cornell University Press 660 p

Six DL (2003) Bark beetle-fungus symbioses. In: Bourtzis K, Miller T (eds) Insect Symbioses. CRS Press, Boca Raton, Florida, USA, pp 97-114

Spalding M, Kainuma M, Collins L (2010) World Atlas of Mangroves. Earthscan, Washington DC, USA, $319 \mathrm{p}$

Steinke TD (1999) Mangroves in South African estuaries. In: Allanson BR, Baird D (eds), Estuaries of South Africa, Cambridge University Press, Cambridge, pp 119-140

Sugiura N (1978) Further analysis of the data by Akaike's information criterion and the finite corrections. Commun Stat Theory Methods 7:13-26

Tamura K, Peterson D, Peterson N, Stecher G, Nei M, Kumar S (2011) MEGA5: molecular evolutionary genetics analysis using maximum likelihood, evolutionary distance, and maximum parsimony methods. Mol Biol Evol 28:2731-2739

Tarigan M, van Wyk M, Roux J, Tjahjono B, Wingfield MJ (2010) Three new Ceratocystis spp. in the Ceratocystis moniliformis complex from wounds on Acacia mangium and A. crassicarpa. Mycoscience 51:53-67

Tarigan M, Roux J, van Wyk M, Tjahjono B, Wingfield MJ (2011) A new wilt and die-back disease of Acacia mangium associated with Ceratocystis manginecans and $C$. acaciivora sp. nov. in Indonesia. S Afr J Bot 77: 292-304

Thwaites JM, Farrell RL, Duncan SM, Reay SD, Blanchette RA, Hadar E, Hadar Y, Harrington TC, McNew D (2005) Survey of potential sapstain fungi on Pinus radiata in New Zealand. N Z J Bot 43:653-663

Tomlinson PB (1986) The Botany of Mangroves. Cambridge University Press, 413 p

Valiela I, Bowen JL, York JK (2001) Mangrove Forests: One of the World's Threatened Major Tropical Environments At least 35\% of the area of mangrove forests has been lost in the past two decades, losses that exceed those for tropical rain forests and coral reefs, two other well-known threatened environments. Bioscience 51:807-815

Van Wyk M, Al Adawi AO, Khan IA, Deadman ML, Al Jahwari AA, Wingfield BD, Ploetz R, Wingfield MJ (2007) Ceratocystis manginecans sp. nov., causal agent of a destructive mango wilt disease in Oman and Pakistan. Fungal Divers 27:213-230 
Villarreal M, Rubio V, de Troya MT, Arenall F (2005) A new Ophiostoma species isolated from Pinus pinaster in the Iberian Peninsula. Mycotaxon 92:259-268

Wang L, Mu M, Li X, Lin P, Wang W (2010) Differentiation between true mangroves and mangrove associates based on leaf traits and salt contents. Journal of Plant Ecology $4: 292-301$

Wen L, Cai X, Xu F, She Z, Chan WL, Vrijmoed LL, Jones EG, Lin Y (2009) Three metabolites from the mangrove endophytic fungus Sporothrix sp.(\# 4335) from the South China Sea. J Org Chem 74:1093-1098

White TJ, Bruns T, Lee S, Taylor J (1990) Amplification and direct sequencing of fungal ribosomal RNA genes for phylogenetics. In: Innis MA, Gelfand DH, Sninsky JJ, White TJ (ed). PCR Protocols: a guide to methods and applications. Academic Press, San Diego, California, USA, pp 315-322

Wingfield MJ, Seifert KA, Webber J (1993) Ceratocystis and Ophiostoma: taxonomy, ecology and pathogenicity. The American Phytopathological Society Press, St. Paul, Minnesota, USA, 293 p

Yin M, Wingfield MJ, a, Zhou X, de Beer ZW (2016) Multigene phylogenies and morphological characterization of five new Ophiostoma spp. associated with spruceinfesting bark beetles in China. Fungal Biol doi:10.1016/j.funbio.2015.12.004

Zanzot J, de Beer ZW, Eckhardt L, Wingfield M (2010) A new Ophiostoma species from loblolly pine roots in the southeastern United States. Mycological Progress 9:447-457

Zhou X, de Beer ZW, Wingfield MJ (2006) DNA sequence comparisons of Ophiostoma spp., including Ophiostoma aurorae sp. nov., associated with pine bark beetles in South Africa. Studies in Mycology 55:269-277 